\title{
Gender equality in Rheumatology
}

\author{
S.L. Bosello ${ }^{1 *}$, M.S. Chimenti ${ }^{2 *}$, P. Conigliaro ${ }^{2 *}$, C. lannuccelli ${ }^{3 *}$, \\ E. Gremese ${ }^{1 *}$, F.R. Spinelli ${ }^{3 *}$, M. Vadacca ${ }^{4 *}$ \\ ${ }^{1}$ UOC di Reumatologia, Fondazione Policlinico Universitario A. Gemelli - IRCCS; \\ ${ }^{2}$ Rheumatology, Allergology and Clinical Immunology, University of Rome Tor Vergata, Rome, Italy; \\ ${ }^{3}$ Reumatologia, Dipartimento di Medicina Interna e Specialità Mediche, Sapienza Università di Roma, \\ Rome, Italy; ${ }^{4}$ Rheumatology, Allergology and Clinical Immunology, Campus Bio Medico

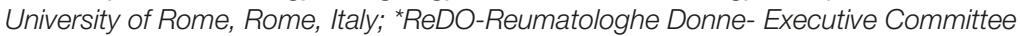

High ighting against inequality is one of the key focus areas chosen by the French presidency of G7 which launched the Gender Equality Advisory Council to Make Gender Inequality History (https://www. elysee.fr/en/g7/2019/08/20/publication-ofthe-report-of-the-g7-gender-equality-advisory-council).

Gender equality is also a central topic in the plan of the European Program Horizon 2020 which includes three main objectives:

1) fostering gender balance in research teams;

2) ensuring gender balance in decisionmaking;

3) integrating the gender dimension in research and innovation contents.

The purpose of this editorial is to point out the issue of gender equality in medicine and to assess the Italian situation in academic rheumatology.

Gender parity is a purely numerical concept; it is a statistical measure that provides a numerical value of female-to-male ratio for indicators such as income or education. For example, if there are equal numbers of girls and boys who completed primary education in a specific country, the gender parity ratio for that indicator is one. The greater the difference between girls and boys, the lower is the gender parity value. Gender parity is a useful tool for assessing gender inequality in specific areas, in setting goals, and in assessing change and progress under specific indicators of gender equality $(1,2)$.

Improvements in gender parity among medical school graduates have not translated to gender parity among practicing physicians or medical schools (3). In 2015, more than one third $(34 \%)$ of the active physician workforce in the United States was female (4); an estimated $46 \%$ of all physicians-in-training and more than half of all medical students are women $(5,6)$. The year 2017 marked the first time in history when the number of women enrolling in US medical schools exceeded the number of men $(7,8)$.

Gender parity does not correspond to gender equality, so much so that gender-based disparities in salaries and advancement persist. A clear demonstration of the inequality in medicine is the difference in women's versus men's salaries. $(3,6,9,10)$.

In the United States and some other developed countries, in cases of equal work and position (same rank, training, and experience), unequal pay continues to disadvantage women (10-13), despite evidence that the quality of care women provide is equivalent, and in some cases superior, to that of their male colleagues (14).

Lower salaries for women compared with men in academic medicine have been attributed to women's lesser productivity, defined by the number of grants and authorship roles $(3,15)$. The gender disparity in research funding is particularly complex to address but clearly evident. A study in JAMA found that the start-up package funding for junior investigators was lower for women performing basic research $(\mathrm{p}<0.001)$ and for women with a PhD degree $(\mathrm{p}<0.001)$ with respect to men $(11$, 12). These are critical differences that can affect an investigator's success in establishing a research program and competing for national research grants. What is clear from this research is that early disparities
Corresponding author: Maria Sole Chimenti Rheumatology, Allergology and Clinical Immunology University of Rome Tor Vergata, Rome, Italy E-mail: msolechimenti@hotmail.com 
in funding between women and men have major career implications that may explain why women do not seem to advance through the scientific career ranks as quickly as men $(11,12)$.

Although equal numbers of men and women now graduate from medical school, only a small fraction of female physicians become medical leaders.

Although women have held faculty positions in academic medicine for decades, women still account for only $21 \%$ of full professors and $15 \%$ of department chairs $(12,16)$. Moreover, the share of females in the faculty declines at each subsequent rank, such that the share of female professors is $56 \%$ lower than the share of male assistant professors $(3,4,16)$. Females holding faculty positions are less likely than male equivalents to be invited to speak at major events, less likely to be introduced with their title when they speak, and less likely to receive awards from their professional societies $(3,17)$.

Female employment is constrained by two kinds of barriers: those at the entry in the labour market and those when progressing through it. These barriers to advancement are also known as the glass ceiling: an invisible mix of cultural attitudes, gender-linked stereotypes, ways of working, lack of policies on the workplace that help balance family care and professional life, which all contribute to the fact that women are retained and promoted less than equally skilled men. There is widespread consensus that putting women at the top of organizations is the most effective way of breaking the glass ceiling: women in decisionmaking positions can change the cultural attitudes, unspoken norms and the ways of working in order for an organization to be more open to promoting women $(1,2)$.

Even if international organizations have done a tremendous job in leading by example in terms of gender parity, the fact that women are still seriously underrepresented at their senior management level is a matter of concern. Disparities in compensation persist, and inequities have contributed to the disproportionately low number of female physicians achieving academic ad- vancement and serving in leadership positions. It is at this level that the presence of more women can radically change cultural attitudes, internal practices and ways of working that otherwise make achieving gender parity more difficult $(2,6)$.

The medical profession and our patients benefit greatly from a diversified physician workforce. A concerted effort must be made to address the systemic inequities that pose as barriers to gender equity in academic medicine careers, to eliminate the imbalance in remuneration and career advancement opportunities and to incorporate women as full participants in our professions $(1,6,12)$.

As explained by the Executive Editor Dr. Jocalyn Clark in a special issue of The Lancet, gender equity is not only a matter of justice and rights, it is crucial for producing the best research and providing the best care to patients (18).

In the rheumatology field, in recent years the proportion of women has been increasing worldwide; in the US the overall number of females currently exceeds the number of male rheumatologists (19). However, women are still underrepresented in academic rheumatology (20, 21). In 2019, EULAR established a task-force on gender equity in rheumatology which will address the potential unmet needs and differences across European countries and delineate opportunities for EULAR to develop a comprehensive intervention on gender equity (22).

As for academic rheumatology in Italy, currently the number of female and male assistant professors is quite similar (49vs $64)$, reflecting the increasing number of females choosing an academic career (Figure 1). The still evident different distribution across the highest academic positions may be related to the greater number of male students attending the medical schools during the last 30 years. In conclusion, even if in recent years parity between the genders has certainly improved, the path to gender equity still has a long way to go, a path to be taken together, driven by the motivation of the medical and non-medical European programs. 


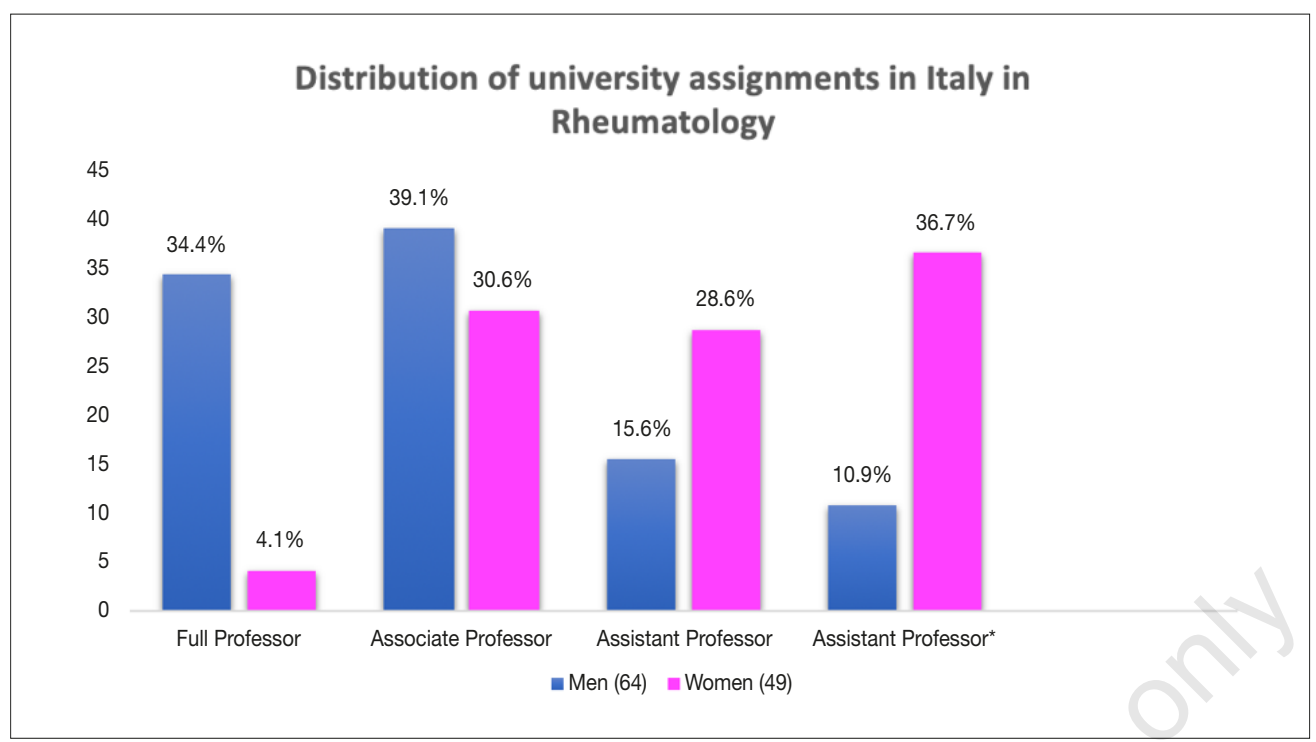

Figure 1 - The increasing number of females choosing an academic career. ${ }^{*}$ Temporary

Note: The authors are members of the Association Reumatologhe Donne (ReDo), a group of doctors whose mission is to promote networking among rheumatologists for women in medicine and science.

\section{REFERENCES}

1. Anne-Marie Sluaghter, Why Women Still Can't Have It All, in «The Atlantic», July/August 2012.

2. European Commission, Strategy on equal opportunities for women and men within the European Commission (2010-2014), 2010, SEC (2010)1554/3

3. Raj A, Kumra T, Darmstadt GL, Freund KM. Achieving Gender and Social Equality: More Than Gender Parity is Needed. Acad Med. 2019 [Epub ahead of print].

4. Association of American Medical Colleges. 2016 Physician Specialty Data Report: Executive Summary. Washington, DC: Association of American Medical Colleges; 2016. Available from: www.aamc.org/download/471786/ data/2016physicianspecialtydatareportexecuti vesummary.pdf Accessed: 22 December 2017.

5. Association of American Medical Colleges. Matriculating Student Questionnaire: 2017 All Schools Summary Report. Washington, DC: Association of American Medical Colleges; 18 December 2017. Available from: www. aamc.org/download/485324/data/msq2017report.pdf Accessed: 29 January 2018.

6. Butkus R, Serchen J, Moyer DV, et al. Achieving Gender Equity in Physician Compensation and Career Advancement: A Position Paper of the American College of Physicians. Ann Intern Med. 2018; 168: 721-3.

7. Kang SK, Kaplan S. Working toward gender diversity and inclusion in medicine: myths and solutions. Lancet. 2019; 393: 579-86.

8. Association of American Medical Colleges. More women than men enrolled in U.S. medical schools in 2017. Available from: https:// news.aamc.org/press-releases/article/applicantenrollment-2017/ Accessed: Sept 14, 2018.

9. Jena AB, Olenski AR, Blumenthal DM. Sex differences in physician salary in US public medical schools. JAMA Intern Med. 2016; 176: 1294-304.

10. Parks AL, Redberg RF. Women in medicine and patients outcomes: equal rights for better work? JAMA Intern Med. 2017; 177: 161.

11. Sege R, Nykiel-Bub L, Selk S. Sex differences in institutional support for junior biomedical researchers. JAMA. 2015; 314: 1175-7.

12. Bates C, Gordon L, Travis E, et al. Striving for Gender Equity in Academic Medicine Careers: A Call to Action. Acad Med. 2016; 91 : 1050-2.

13. Jena AB, Olenski AR, Blumenthal DM. Sex differences in physician salary in US public medical schools. JAMA Intern Med. 2016; 176: 1294-304.

14. Wallis CJ, Ravi B, Coburn N, et al. Comparison of postoperative outcomes among patients treated by male and female surgeons: A population based matched cohort study. BMJ. 2017; 359: j4366.

15. Filardo G, da Graca B, Sass DM, et al. Trends and comparison of female first authorship in high impact medical journals: Observational study (1994-2014). BMJ. 2016; 352: i847. 
16. Lautenberger DM, Dandar VM, Raezer CL, Sloane RA. The State of Women in Academic Medicine: The Pipeline and Pathways to Leadership 2013-2014. Washington, DC: Association of American Medical Colleges. 2014.

17. Boiko JR, Anderson AJ, Gordon RA. Representation of women among academic grand rounds speakers. JAMA Intern Med. 2017; 177: 722-4.

18. The Lancet. Feminism is for everybody. Lancet. 2019; 393: 493.

19. Deal C, Bolster MB, Hausmann JS, et al. Adult rheumatology specialists in the United
States: effect of gender and generation. Arthritis Rheumatol. 2016; 68.

20. Elston MA. Women and medicine: the future. London: Royal College of Physician. 2009.

21. Edmunds LD, Ovseiko PV, Shepperd S, et al. Why do women choose or reject careers in academic medicine? A narrative review of empirical evidence. Lancet 2016; 388: 2948-58.

22. Andreoli L, Ovseiko PV, Hassan N, et al. Gender equity in clinical practice, research and training: Where do we stand in rheumatology? Joint Bone Spine. 2019 [Epub ahead of print]. 